\title{
CONTRACTUAL NETWORKS IN EUROPEAN PRIVATE INTERNATIONAL LAW
}

\section{Dr Uglješa Grušić*}

Abstract: This article examines private international law issues raised by transnational contractual networks. The focus is on choice-of-law questions that arise in the context of 1) relations between network members who are contractually bound to one another, 2) relations between network members not connected directly by bonds of contract, and 3) relations between the network and the outsiders. The aim is to assess whether, and to what extent, European private international law is capable of dealing with some of the key challenges posed by contemporary economic and social activity.

Keywords: private international law; conflict of laws; contractual networks; choice of law; EU law; Rome I; Rome II; contract; tort

'The line between what is inside and what is outside the corporation, once so clear, has become blurred... Firms such as Nike have stretched this idea to such an extent that some of them now make nothing: all Nike's shoes, for instance, are manufactured by subcontractors. Nike employs few people directly. Such companies have become the orchestrators of a band. Their baton has only limited control over the musicians who play for them, but 
that does not prevent them from producing great music (or

shoes).' 1

\section{INTRODUCTION}

The way in which economic productive activity is coordinated is undergoing profound changes. The traditional, vertically-integrated firm is increasingly giving way to flexible forms of business organisation, which are characterised by a great degree of autonomy and interdependence of their constituent parts. Members of the modern economic enterprise are often not connected by bonds of ownership, but are ever more frequently independent firms bound together through long-term cooperative contractual and quasi-contractual relations or informal alliances. Such inter-organisational associations are far removed from both traditional corporations and discrete, spot, arm's length transactions that occur in the market, which are the two paradigmatic types of relation that are the concern of company law and contract law, respectively. Relations between independent firms that pursue a common purpose without creating a new legal entity are defined by long-term duration, stability, multilaterality and the creation of governance structures for the coordination of economic activity and the exchange of knowledge and information. The term 'contractual network' is used in this article to capture this phenomenon. ${ }^{2}$

Such modern forms of business organisation that go beyond the hierarchy-market and corporation-contract dichotomies have proven to be very good at coming up with innovative

\footnotetext{
* Assistant Professor, University of Nottingham. This article will be published in (2016) 65 ICLQ.

${ }^{1}$ The Economist, 21 January 2006, special report on 'The New Organisation: A Survey of the Company', 18.

2 The following terms have also been used in the literature: business networks; quasi-organisations; quasi-firms; virtual enterprises; multi-party hybrid business arrangements; complex economic organisations. See H Collins, 'Introduction' in G Teubner, Networks as Connected Contracts (Hart, 2011), 12.
} 
products and services, retaining and expanding their base of customers and tapping into new markets. Since they naturally flow from the processes of decentralisation of economic activity, vertical disintegration of firms, privatisation, deregulation and globalisation, they have become a ubiquitous phenomenon in modern market capitalist economies.

The 'new organisation'3 poses significant challenges for the law. Generally speaking, lawyers think in terms of categories. Contract, tort, company law etc. are among the foundational concepts of modern legal systems that define our thinking about private law. This is reflected in an obvious manner in private international law. The Recast of the Brussels I Regulation, ${ }^{4}$ for example, lays down different rules of special jurisdiction for contractual and tortious matters in Articles 7(1) and 7(2), respectively. The fault line is even deeper in choice of law, where contractual and non-contractual obligations fall within the subject-matter scope of two different regulations: Rome ${ }^{5}$ and Rome II. ${ }^{6}$ Company law issues are treated as a wholly different animal and accordingly given a special treatment in the law of adjudicatory jurisdiction ${ }^{7}$ and placed outside the subject-matter scope of the two Rome Regulations. ${ }^{8}$ And there are further divisions within these sub-systems of private law. General contract law, for example, is different from the law of labour and consumer contracts. But, as contractual networks show, life does not fit squarely into legal moulds. Being beyond hierarchy and market, contractual networks are hard to squeeze into the established legal categories of

\footnotetext{
${ }^{3}$ The Economist (n 1).

${ }^{4}$ Regulation (EU) No 1215/2012 of the European Parliament and of the Council of 12 December 2012 on jurisdiction and the recognition and enforcement of judgments in civil and commercial matters (recast) [2012] OJ L351/1. The Recast replaces Council Regulation (EC) No 44/2001 of 22 December 2000 on jurisdiction and the recognition and enforcement of judgments in civil and commercial matters [2001] OJ L12/1, which replaced the Convention of 27 September 1968 on jurisdiction and the enforcement of judgments in civil and commercial matters [1972] OJ L299/32. See also the two Lugano Conventions on jurisdiction and the recognition and enforcement of judgments in civil and commercial matters of 1988 ([1988] OJ L319/9) and 2007 ([2009] OJ L147/1).

${ }^{5}$ Regulation (EC) No 593/2008 of the European Parliament and of the Council of 17 June 2008 on the law applicable to contractual obligations (Rome I) [2008] OJ L177/6, which replaces the Convention on the law applicable to contractual obligations, opened for signature in Rome on 19 June 1980 [1980] OJ L266/1.

${ }^{6}$ Regulation (EC) No 864/2007 of the European Parliament and of the Council of 11 July 2007 on the law applicable to non-contractual obligations (Rome II) [2007] OJ L199/40.

7 See Art 24(2) Brussels I Recast.

${ }^{8} \operatorname{Art~1(2)(f)~and~(g)~Rome~I;~Art~1(2)(d)~Rome~II.~}$
} 
contract, tort and company law. Being defined in functional terms, they sometimes straddle the fault lines between commercial, consumption, employment etc. relations.

Contractual networks do not only cut across entrenched legal classifications, but also across national boundaries. In Europe, for example, where fundamental economic freedoms are guaranteed, many contractual networks operate transnationally and are significant generators of economic output. Or, as the example of Nike mentioned in the quote above demonstrates, some transnational contractual networks are true global economic players. One would therefore expect private international lawyers, especially European ones, to be at the forefront of the research of this phenomenon and its legal regulation, in particular because contract and company lawyers who have taken an interest in contractual networks have tended not to take a transnational view of the problems that they generate and have examined them largely from the perspective of their own national legal systems. ${ }^{9}$ Surprisingly, however, not much attention has been given to this phenomenon in private international law. As will be explained in the following section, contractual networks raise three distinct types of problems concerning: 1) relations between network members who are contractually bound to one another; 2) relations between network members not connected directly by bonds of contract; and 3) relations between the network and the outsiders. Private international law scholarship has so far focused on specific types of contractual relations that fall within the general concept of a contractual network (e.g. distribution, construction, franchise, commercial agency contracts) and, even more specifically, on the problems of the first type mentioned above. ${ }^{10}$

\footnotetext{
${ }^{9}$ A reason for this approach of substantive lawyers may be found in what Collins (n 2) describes, at p 28, as a 'double impossibility': 'The problem of comparative sociological jurisprudence is doubly impossible, because it adds to the existing problem of finding adequate modes of communication between law and socio-economics the further problem of establishing communications (or transplants) between autonomous national legal systems.'

${ }^{10}$ See e.g. M-E Ancel, 'The Rome I Regulation and Distribution Contracts' (2008) 10 YBPIL 221; RH Christie, 'The Law Governing an International Construction Contract' (2007) 24 International Construction Law Review 343; L Garcia Gutierrez, 'Franchise Contracts and the Rome I Regulation on the Law Applicable to International Contracts' (2008) 10 YBPIL 233; P Mankowski, 'Commercial Agents under European Jurisdiction Rules: The Brussels I Regulation Plus the Procedural Consequences of Ingmar' (2008) 10 YBPIL 197; P Piroddi,
} 
This article tackles two questions. First, will private international law benefit from the introduction of the concept of a contractual network into legal discourse? Second, what are the implications of the introduction of this concept for the legal regulation, practice and scholarship? In addressing these questions, this article examines whether, and to what extent, private international law raises to some of the key challenges posed by contemporary economic and social activity. The investigation is undertaken from the perspective of European private international law. The focus is not on any specific type of contractual relations that falls within the general concept of a contractual network. This phenomenon is rather explored in a holistic manner. Consequently, the aim of this article is not to offer an indepth analysis of all private international law issues that are potentially raised by all kinds of network contracts but primarily to set the foundations for discussion and future research.

The following section (section II) looks more closely into the concept of a contractual network. By highlighting distinctive features of contractual networks, the scene is set for the discussion of the role of European private international law in regulating transnational networks (section III) and of private international law issues raised by internal (sections IV and V) and external (section VI) aspects of transnational networks. It is revealed that the rules of European private international law and its mode of reasoning are by and large struggling to accommodate this phenomenon. The final section (section VII) concludes and mentions several possible ways of improving the law.

\footnotetext{
'International Subcontracting in EC Private International Law' (2005) 7 YBPIL 289. Compare F Cafaggi and S Clavel, 'Interfirm Networks across Europe: A Private International Law Perspective' in F Cafaggi (ed), Contractual Networks, Inter-Firm Cooperation and Economic Growth (Cheltenham: Edward Elgar, 2011) 201; F Cafaggi, 'Contractual Networks and the Small Business Act: Towards European Principles?' (2008) 4 European Review of Contract Law 493 (these two articles examine the concept of a contractual network from the perspective of private international law in a holistic manner; their main shortcoming is that they do not address external aspects of contractual networks, i.e. problems of the third type mentioned above) and H Muir Watt, 'Governing Networks: A Global Challenge for Private International Law' (2015) 22 Maastricht Journal of European and Comparative Law 352 (the focus of this article is on external aspects of contractual networks).
} 


\section{THE CONTRACTUAL NETWORK: THE CONCEPT AND DISTINCTIVE FEATURES}

Contractual networks have generated a lot of interest among substantive lawyers. ${ }^{11}$ This section will therefore limit itself to outlining the concept of a contractual network and its distinctive features to the extent necessary to support the private international law discussion that follows in subsequent sections of this article.

Defining contractual networks is not easy. Several definitions have been put forward in legal scholarship, thus adding to numerous definitions from other branches of the social sciences such as economics, sociology and business studies. According to Teubner, contractual networks are 'modes of organising economic activities that bind formally independent firms who are more or less economically dependent upon one another through stable relationships and a complex reciprocity that is more cooperative than competitive in form. ${ }^{12}$ Similarly, Collins defines contractual networks as associations of independent firms 'that enter a pattern of interrelated contracts, which are designed to confer on the parties many of the benefits of co-ordination achieved through vertical integration in a single firm, without in fact ever creating a single integrated business entity such as a corporation or a partnership.' ${ }^{, 13}$

\footnotetext{
${ }^{11}$ See e.g. M Amstutz and G Teubner (eds), Networks: Legal Issues of Multilateral Co-operation (Hart, 2009); D Campbell, H Collins and J Wightman (eds), Implicit Dimensions of Contract: Discrete, Relational and Network Contracts (Hart, 2003); Cafaggi (n 10); H Collins, Regulating Contracts (OUP, 1999), Ch 10; S Grundmann, F Cafaggi and G Vettori (eds), The Organizational Contract: From Exchange to Long-Term Network Cooperation in European Contract Law (Leiden, Netherlands; Burlington, Vermont: Ashgate, 2013); Teubner, Networks as Connected Contracts, with introduction by Collins (n 2).

${ }^{12}$ Teubner (n 2), 92. Teubner borrows this definition from J Sydow, Strategische Netzwerke: Evolution und Organisation (Wiesbaden: Gabler, 1992), 82.

${ }^{13}$ Collins (n 2), 1; see also H Collins, 'Introduction: The Research Agenda of Implicit Dimensions of Contracts' in Campbell, Collins and Wightman (eds) (n 11), 19-20 and H Collins, 'The Weakest Link: Legal Implications of the Network Architecture of Supply Chains' in Amstutz and Teubner (eds) (n 11) 187. Similarly, JN Adams and R Brownsword, 'Privity and the Concept of a Network Contract' (1990) 10 Legal Studies 12, 27-8.
} 
As is clear from these definitions, the concept of a contractual network is primarily an economic and sociological one. In order to understand it better, it is useful to look briefly into the reasons for its existence, as well as to compare and contrast it with related phenomena.

Economic actors are always faced with the 'make or buy' dilemma. For example, sellers of products must decide whether to make a product on their own or to turn to the market for the acquisition of necessary inputs. A decision to make represents the basis for the establishment of vertically-integrated firms where labour is divided among employees whose work is coordinated by managers. A decision to buy results in the creation of contractual relations in the market. The job of economists is to explain why some economic activities are conducted through firms, whereas other similar activities occur through market transactions. ${ }^{14}$ For present purposes, suffice it to say that the two basic reactions to the make or buy dilemma are at the core of the hierarchy-market dichotomy, which is conceived in legal terms as the paradigmatic binary divide between the corporation and the discrete, arm's length, bilateral contractual relation with relatively bounded obligations that are performed instantaneously.

There are, however, other forms of coordination of economic productive activity. ${ }^{15}$ Sometimes, the efficient response to ex ante uncertainty, e.g. about the development of market conditions, is achieved neither through production in a vertically-integrated firm, nor through one-off exchanges in the market, but through long-term cooperative contractual relations. Due to their intended long-term, perhaps indefinite, duration and the surrounding uncertainty, such relations are necessarily incomplete by design. One party is expected to utilise its special skills, knowledge or information to act in the best interest of the other party and typically under the other party's instructions. This gives rise to the principal-agent

\footnotetext{
${ }^{14}$ Seminally, RH Coase, 'The Nature of the Firm' (1937) 4 Economica 386.

15 See generally Collins (n 2), 4-13; Collins (n 11), Ch 10; S Grundmann, F Cafaggi and G Vettori, 'The Contractual Basis of Long-Term Organization - The Overall Architecture' in Grundmann, Cafaggi and Vettori (eds) (n 11) 3, 6-28; WW Powell, 'Neither Market nor Hierarchy: Network Forms of Organization' (1990) 12 Research in Organisational Behaviour 295.
} 
problem. In order to deal with the risk of opportunism and free-riding on the part of the agent, and to protect its sunk investments, the principal typically establishes governance structures that enable it to supervise, monitor, incentivise and discipline the agent. These governance structures construct relations of power and domination, which can be abused by the principal. This theoretical model of 'relational' $\operatorname{contracts}^{16}$ is, however, incomplete. Most importantly, many long-term cooperative contractual relations are of a 'symbiotic' nature, ${ }^{17}$ characterised by two principal and agent relations, in which both parties act as the agent for the other party and, therefore, also as a principal. The law is confronted with the question of whether the general rules of contract law should be modified in the light of specific features of relational and symbiotic contracts, e.g. by creating adequate default and mandatory rules to secure trust between the parties and to protect and enhance the efficient operation of these contractual arrangements.

There is a significant degree of overlap between the concepts of relational and symbiotic contracts and contractual networks. The theoretical model of contractual networks, however, emphasises the added dimension of multilaterality. Networks involve a collection of contractual relations, often symbiotic and relational, between multiple parties. The overall economic success of the network, i.e. the fulfilment of the network purpose, depends on the interaction, interdependence and cooperation of both members who are contractually bound to one another and members who are not immediate contractual parties. This requires the establishment of adequate structures, legal and non-legal, for the coordination of economic activity and the exchange of knowledge and information. Typical examples of contractual networks include franchise, distribution and commercial agency networks, production and

\footnotetext{
${ }^{16}$ I Macneil, The Relational Theory of Contract: Selected Works of Ian Macneil (London: Sweet \& Maxwell, 2001); see also Collins, 'Introduction' in Campbell, Collins and Wightman (eds) (n 11), 18-24.

${ }^{17}$ C Kirschner, 'Symbiotic Arrangements as a Challenge to Antitrust' (1996) 152 Journal of Institutional and Theoretical Economics 226; E Schanze, 'Symbiotic Contracts: Exploring Long-term Agency Structures between Contract and Corporation' in C Joerges (ed), Franchising and the Law (Baden Baden: Nomos, 1991) 67; E Schanze, 'Symbiotic Arrangements' (1993) 149 Journal of Institutional and Theoretical Economics 691; see also Collins (n 11), 239-41.
} 
supply chains, joint venture agreements, construction contracts, credit transfer networks, credit arrangements between banks, retailers and purchasers, temporary agency work etc.

Contractual networks pose significant challenges for the law. The essential feature of contractual networks is the inherent tensions between different logics of action, which open up certain regulatory questions. ${ }^{18}$ Firstly, there is the tension between bilateral exchange and the logic of association. The model of contractual networks shows that the network as a whole has a purpose that transcends the interests of individual members and the purposes of bilateral contracts that form the network. But, since individual members of the network remain independent firms with their own particular and divergent interests, the network purpose and the interests of network members can never be fully aligned in all respects. This creates opportunities and incentives for disappointment and betrayal. The question arises whether the law should acknowledge this and infuse bilateral relations between network members with network-specific obligations such as a general duty of loyalty to the network purpose.

A related tension concerns relations between network members who are not in a direct contractual relation with one another. The model of contractual networks demonstrates that the opportunistic behaviour of one network member can cause economic harm not only to network members with whom it has a direct contractual relation, but also to other members or the network as a whole. Can such 'third party' network members go around the doctrine of privity of contract and bring a successful claim against the free rider for causing them economic harm by undermining the network purpose and, if so, on what basis?

The final tension concerns the relationship between the network as a multilateral construction of bilateral contracts and the outsiders. Whenever harm is caused to an outsider, regardless of whether or not the fault lies entirely with the network member who is in a direct

\footnotetext{
${ }^{18}$ Collins (n 2), 14-8; Teubner (n 2), 178.
} 
relationship with the third party victim, the network typically emphasises that its members are independent firms and that their liabilities are separate. This is often in contrast to the image that the network portrays to the general public. As a result, whereas all network members benefit from the advantages derived from the network as a whole, the external risks generated by the network's economic activity are typically confined to the firm with direct exposure to the victim. The question arises whether the network as a whole or at least network members that somehow contributed to the harm - as opposed to just the individual network member who is directly exposed to the third party victim - should be made liable for damage caused to third parties and, similarly, whether third parties should be made liable to the network for the harm that they inflict on it. A related question that arises with respect to external aspects of contractual networks pertains to the membership of the network. Who is in and who is out? Should consumers in credit arrangements between banks, retailers and purchasers be treated as network members? What about workers in temporary agency work relations?

Before proceeding further, a line should be drawn between contractual networks, which are the subject of this article, and a similar phenomenon of organisational networks. ${ }^{19}$ Organisational networks are corporate groups, comprised of separate legal entities which are typically connected by bonds of ownership that establish hierarchical relations within the group, relatively clear management rights and organisational competencies. The built-in hierarchies are the primary feature of corporate groups, enabling coordination and the pursuance of the group's collective purpose or aim. Contractual networks are a different animal. They are forms of market coordination and are primarily subject to market logic. 'The primary concern is with exchange, competition, individual interests and individual actor rents... Within market networks, influence is primarily exercised by means of contract,

\footnotetext{
19 Teubner (n 2), 133-9.
} 
bargaining, opposing power, market power and exchange positions $\cdot{ }^{20}$ Furthermore, corporate groups are a well-established and recognised phenomenon, which the law regulates - to a greater or lesser extent - through special corporate, competition, labour, tax law, accounting etc. rules. Contractual networks, on the other hand, are a wide-spread phenomenon for which specific legal regulation is largely absent.

\section{EUROPEAN PRIVATE INTERNATIONAL LAW AND REGULATION OF} TRANSNATIONAL CONTRACTUAL NETWORKS

Challenges posed by contractual networks are particularly important from the European perspective. Small and medium enterprises, which are the motors of European economies, are the most likely firms to form these inter-organisational associations. In order to facilitate the creation of networks, and to unlock the synergies that they produce, it is not enough for European law to guarantee fundamental economic freedoms. The law should also protect and enhance the efficiency of networks by contributing to the normalisation and stabilisation of their inherent tensions, securing trust, while also countering the risks that they create. One way to achieve this is through unified and harmonised regulation at the European level. ${ }^{21}$ But it is unlikely that this will be achieved, in the short- and mid-term at least. Consequently, as long as the regulation of contractual networks remains at national level with many different substantive law solutions to the regulatory questions that contractual networks open up,

\footnotetext{
${ }^{20}$ Ibid, 138.

${ }^{21}$ See Cafaggi, 'Contractual Networks and the Small Business Act: Towards European Principles?' (n 10); C Cafaggi, 'Contractual Networks and Contract Theory: A Research Agenda for European Contract Law' in Cafaggi (ed) (n 10) 66; F Cafaggi and S Grundmann, 'Towards a Legal Framework for European Transnational Networks?' in Grundmann, Cafaggi and Vettori (eds) (n 11) 358.
} 
European private international law continues to be a crucial mechanism for the coordination of legal diversity that exists in Europe.

It is well established that private international law in general, and European private international law in particular, are performing important regulatory functions. ${ }^{22}$ A question for European private international law is whether the objectives pursued by its jurisdictional and choice-of-law rules, as well as the rules themselves or their interpretation and application, should be modified in the light of distinctive features and economic importance of transnational contractual networks. The reason there are uniform private international law rules in the European Union is to enhance the proper functioning of the internal market. ${ }^{23}$ Since transnational contractual networks are a ubiquitous and important form of coordination of economic productive activity, and in the absence of substantive transnational regulation of this phenomenon, European private international law should take a conscious, active and positive role in their regulation. One must agree with Cafaggi and Clavel that European private international law should aim to foster cooperation and coordination in the network and thereby protect and enhance their efficient operation. ${ }^{24}$ In addition, and this is an important point that is neglected by most private international lawyers who have written about contractual networks, ${ }^{25}$ European private international law should help counter the risks that networks create. Whether European private international law is capable of achieving these

\footnotetext{
${ }^{22}$ On the regulatory function of private international law see R Michaels, 'New European Choice-of-Law Revolution' (2008) 82 Tulane Law Review 1607; A Mills, The Confluence of Public and Private International Law: Justice, Pluralism and Subsidiarity in the International Constitutional Ordering of Private Law (CUP, 2009); H Muir Watt, 'Choice of Law in Integrated and Interconnected Markets: A Matter of Political Economy' (2003) 9 Columbia Journal of European Law 383; H Muir Watt, 'Integration and Diversity: The Conflict of Laws as a Regulatory Tool' in F Cafaggi (ed), The Institutional Framework of European Private Law (OUP, 2006) 107; H Muir Watt, 'Private International Law Beyond the Schism' (2011) 2 Transnational Legal Theory 347; R Wai, 'Transnational Liftoff and Juridical Touchdown: The Regulatory Function of Private International Law in an Era of Globalization' (2002) 40 Columbia Journal of Transnational Law 209.

${ }^{23}$ See Art 81 of the Treaty on the Functioning of the EU (consolidated version) [2012] OJ C326/47 (TFEU); Recitals 3 and 4 Brussels I Recast; Recitals 1 and 6 Rome I; Recitals 1 and 6 Rome II.

${ }^{24}$ (n 10), 206.

${ }^{25}$ See $\mathrm{n} 10$ above.
} 
objectives is a question for the following three sections that concern internal and external aspects of contractual networks in private international law.

The focus of this article is on choice-of-law issues raised by transnational contractual networks. This is because the law of adjudicatory jurisdiction seems capable of dealing relatively well with the network phenomenon, since many jurisdictional bases are not grounded in the distinction between contract, tort, company law etc. Most importantly, there are jurisdictional rules that are based on the connection between different defendants and different claims. Thus, an EU domiciliary who is one of a number of defendants can be sued in the courts for the place in the EU where any of the co-defendants is domiciled, provided the claims are sufficiently closely connected. ${ }^{26}$ To take another example, the traditional English law of jurisdiction, which applies, generally speaking, to determine the jurisdiction of English courts over non-EU domiciliaries, lays down a similar rule in para 3.1(3) of the Civil Procedure Rules Practice Direction 6B. This rule which provides for the possibility of commencing proceedings against a person who is a necessary or proper party to a claim that is already pending between the claimant and another defendant. The existence of these and other jurisdictional rules under which the nature of the claim is immaterial mitigates the problems raised by transnational contractual networks. But networks do present certain difficulties with regard to jurisdictional rules that are based on the distinction between contract, tort, company law etc, as exemplified by the case law of the Court of Justice of the European Union (CJEU) and the courts of EU Member States dealing with Articles 7(1) and 7(2) of the Brussels I Recast and their predecessors, ${ }^{27}$ and with regard to the personal scope of choice-of-court clauses. $^{28}$

\footnotetext{
${ }^{26}$ Art 8(1) Brussels I Recast. See also Art 8(2) (third party proceedings) and 8(3) (counter-claims).

${ }^{27}$ On the delimitation of the spheres of application of Arts 7(1) and 7(2) see Case C-26/91 Jakob Handte \& Co GmbH v Traitements Mécano-chimiques des Surfaces SA [1992] ECR I-3967 and the recent Case C-548/12 Brogsitter v Fabrication de Montres Normandes ECLI:EU:C:2014:148, [2014] QB 753, noted by A Dickinson, 'Towards an Agreement on the Concept of “Contract” in EU Private International Law?' [2014] LMCLQ 466. In
} 
When examining choice-of-law issues in the context of contractual networks, one should keep in mind the distinction made by Brownsword between voluntary and imposed networks in contracts. ${ }^{29}$ According to him, there are two justificatory bases for holding parties to a set of rules governing network relations. One justification rests on freedom of contract, in the sense that the parties have freely chosen to be bound by such rules. The other justification relies on the merits of the rules themselves. The parties are bound by a particular set of rules governing network relations not because they have been freely chosen, but because they are right by reference to certain objective criteria such as efficiency or fairness. Consequently, the law should, in principle, support the parties' choice to create freely a particular kind of governance structure for their transactions, which includes the freedom to choose the legal regime applicable to network relations. Rules governing network relations, including the applicable substantive law, should be imposed only if justified on the basis of objective criteria. This distinction between procedural and substantive justifications for the application of the network concept is important because it provides a useful framework for the assessment of the European choice-of-law rules, some of which give effect to party autonomy and some of which apply in the absence and even irrespective of the parties' choice.

\section{CHOICE OF LAW AND INTERNAL ASPECTS OF NETWORKS 1: RELATIONS BETWEEN CONTRACTUALLY BOUND NETWORK MEMBERS}

\footnotetext{
addition, the rules of jurisdiction in contract and tort are difficult to apply to transnational contractual networks whenever the performance of the contract or the harmful event occur in more than one State: see U Grušić, 'Jurisdiction in Complex Contracts under the Brussels I Regulation' (2011) 7 JPIL 321; M Lehmann, 'Where does Economic Loss Occur?' (2010) 7 JPIL 527.

${ }^{28}$ See Case C-543/10 Refcomp SpA v Axa Corporate Solutions Assurance SA ECLI:EU:C:2013:62, [2013] 1 Lloyd's Rep 449; Muir Watt (n 10), 362-4.

${ }^{29}$ R Brownsword, 'Network Contracts Revisited' in Amstutz and Teubner (eds) (n 11) 31.
} 
Relations between the members of a network who are contractually bound to one another are classified as contractual in nature, thus falling within the subject-matter scope of Rome I. ${ }^{30}$ The basic scheme of this instrument is as follows. There are special choice-of-law rules for carriage, consumer, insurance and employment contracts, which are contained in Articles 5-8, respectively. The special rules limit the freedom of the parties to choose the applicable law and are based on connecting factors that reflect the peculiar features of these contracts. Other contracts fall under the general rules of Articles 3 and 4 . Article 3 allows the parties to choose the applicable law. Article 4 sets out the default choice-of-law rules that are applicable in the absence of party autonomy. Finally, Article 9 allows the courts to apply the so-called overriding mandatory provisions of the law of the forum and, under certain conditions, even the overriding mandatory provisions of the law of the country of performance.

The basic scheme of Rome I raises three questions. Firstly, are the general rules of Articles 3 and 4, which apply in the vast majority of cases concerning transnational contractual networks, capable of fostering cooperation and coordination in the network? The second question pertains to networks (e.g. a credit card transaction and temporary agency work) that comprise contracts that fall within the scope of more than one set of choice-of-law rules. Can the simultaneous application of more than one set of choice-of-law rules lead to network-favourable outcomes? Thirdly, how do overriding mandatory provisions affect the objectives of cooperation and coordination? These questions will be addressed in turn.

\section{A. General Choice-of-Law Rules of Rome I and Contractual Networks}

\footnotetext{
${ }^{30}$ Art 1 Rome I.
} 
Having in mind the distinction between procedural and substantive justifications for the application of the network concept ${ }^{31}$ choice of law by network members and choice of law by the default choice-of-law rules will be assessed separately.

\section{Choice of law by network members}

The parties can choose the legal regime applicable to network relations either directly, i.e. by creating or referring to an existing set of rules governing network relations (e.g. produced by a transnational trade or business association), or indirectly, i.e. by choosing the applicable law that contains rules governing network relations. The difference between the choice of nonstate rules of law and the choice of a national law to govern a contractual relation is well known in private international law. Rome I does not acknowledge the choice of a non-state body of law as the choice of law governing the contract for the purposes of Article 3 . The most that the parties can do under Rome I is to incorporate non-state rules of law into their contract, which will be given effect to the extent allowed by the national law governing the contract. ${ }^{32}$ In other words, Rome I subscribes to the orthodox view expressed famously by Lord Diplock in Amin Rasheed Shipping Corporation v Kuwait Insurance Co ${ }^{33}$ that:

contracts are incapable of existing in a legal vacuum. They are mere pieces of paper devoid of all legal effect unless they were made by reference to some system of private law which defines the obligations assumed by the parties to the contract by

\footnotetext{
${ }^{31}$ See text accompanying n 29 above.

${ }^{32}$ See Recital 13 Rome I ('This Regulation does not preclude parties from incorporating by reference into their contract a non-State body of law or an international convention.'). Compare Art 3(2) of the proposal for Rome I, $\operatorname{COM}(2005) 650$ final and Art 3 of the Hague Principles on Choice of Law in International Commercial Contracts, Hague Conference on Private International Law, Prel. Doc. No 6 - revised of July 2014.

33 [1984] AC 50 (HL), 65.
} 
their use of particular forms of words and prescribes the remedies enforceable in a court of justice for failure to perform any of those obligations.

The choice of non-state rules of law by the parties will, generally speaking, be given effect because of the principle of freedom of contract that is at the heart of modern national systems of contract law; but non-state rules of law will be given effect only to the extent to which they do not clash with non-derogable rules of the national law that governs the contract.

The fact that every contract must have a governing national law has important consequences for the objectives of cooperation and coordination in the network. Since every bilateral contractual relation in a network must be governed by a national law, the risk of conflict and contradiction potentially arises whenever the members of a transnational contractual network choose a non-state body of law to govern network relations. It should be noted in this respect that contractual networks usually take one of the following three forms. Firstly, in many networks there is a more or less clear centre, the hub of the network, which enters explicit contractual relations with other network members. This type of network is organised in a hub and spokes or star pattern. A typical example is a franchise in which the franchisor stands at the centre of the network and has direct contractual relations with franchisees; franchisees are not bound to one another by express contractual stipulations. Secondly, some networks are organised as chains of contracts, for example supply chains. Thirdly, there are mixed networks that combine both hub and spokes and chain patterns, such as construction contracts. If a network is organised in a chain pattern, the national law that governs one bilateral contract that forms part of the network might acknowledge a general duty of loyalty towards the network and enable the review of the content of standard form contracts entered into between network members, which might include the review of the nonstate body of law chosen to govern network relations. But the national laws that govern bilateral contracts up and down the chain might not take the network purpose into account in 
the interpretation of bilateral contracts that form a network or might contain different, conflicting and contradictory rules. This, in turn, might affect the passing of liabilities along the chain. A related problem arises in contractual networks that are organised in a hub and spokes pattern. The bilateral contracts entered into by the hub of a network might be governed by different national laws which might interact in different, conflicting and contradictory ways with one other and with the non-state body of law agreed between the hub and nodes to govern network relations. Whether conflict and contradiction will in fact arise depends largely on whether the bilateral contractual relations that form a network will in fact be governed by different national laws, which ultimately depends on the operation of the default choice-oflaw rules.

Before moving to the assessment of the default choice-of-law rules, the choice of national law by the parties to govern network relations should be addressed. Can the members of a network achieve the desired unity of applicable law by choosing one national law to govern all bilateral contractual relations that form the network or, alternatively, by choosing one national law to govern network-related issues? Choice of law by the parties can be either express or tacit. An express choice can be made by using the same choice-of-law clause in all bilateral contracts or by referring therein to the same document (e.g. a framework agreement) that contains a choice-of-law clause in favour of a national law. Tacit or implied choice, on the other hand, is a real choice of law that is not expressed in the contract, but is "clearly demonstrated by the terms of the contract or the circumstances of the case'. ${ }^{34}$ The question arises of whether, in cases where some of the bilateral contracts that form a network are silent about the applicable law, the courts can infer a choice of law on the ground that another network contract contains an express choice of law. Although this situation is not mentioned

\footnotetext{
${ }^{34}$ Art 3(1) Rome I.
} 
in the non-exhaustive list of examples of implied choice in the Giuliano-Lagarde Report, ${ }^{35}$ there is no reason why a choice of law in a network contract cannot be inferred on the ground of an express choice of law in a contract that forms part of the same network. This seems to be confirmed by the Green Paper on the conversion of the Rome Convention into a Community instrument according to which an implied choice can be found where a contract is 'part of a series of operations, the law having been chosen only for the basic contract underlying the general operation'. ${ }^{36}$ Further support for this argument is found in a recent empirical study by Penades Fons on the finding of implied choice of law and the use of the escape clause in the context of Rome I. ${ }^{37} \mathrm{He}$ demonstrates that the flexible approach by English courts to the finding of implied choice is justified as a response to the need to balance the multiple policy issues generated by international commercial transactions. Protecting and enhancing the efficient operation of transnational contractual networks should be one of the goals of European law, including European private international law. The flexible approach to the finding of implied choice of law that would lead to the desired unity of applicable law to a contractual network should therefore be regarded as justified and in line with the approach of the courts to the finding of implied choice. ${ }^{38}$ But this flexible approach has its limits - it can

\footnotetext{
${ }^{35}$ M Giuliano and P Lagarde, 'Report on the Convention on the Law Applicable to Contractual Obligations' [1980] OJ C282/1, para 3 of the comment of Art 3.

${ }^{36}$ European Commission, Green paper on the conversion of the Rome Convention of 1980 on the law applicable to contractual obligations into a Community instrument and its modernisation, $\operatorname{COM}(2002) 654$ final, section 3.2.4.1.

${ }^{37}$ M Penades Fons, 'Commercial Choice of Law in Context: Looking Beyond Rome' (2015) 78 MLR 241.

${ }^{38}$ Penades Fons concludes ibid, at $\mathrm{p} 256$, that 'the application of the doctrine of connected contracts under either implied choice or the escape clause is used as a mechanism to enhance the commercial soundness of the operation. That is, as an instrument for the unification of the legal order applicable to the plurality of agreements constituting a transaction or a chain of transactions.' English cases on implied choice in related contracts include Groupama Navigation et Transports v Catatumbo CA Seguros [2000] 2 Lloyd's Rep 350 (CA) (reinsurance); Emeraldian Ltd Partnership v Wellmix Shipping Ltd [2010] EWHC 1411 (Comm), [2011] 1 Lloyd's Rep 301, [170] (guarantee related to a charterparty); FR Lurssen Werft GmbH \& Co KG v Halle [2010] EWCA Civ 587, [2011] 1 Lloyd's Rep 265, [20]-[21] (commission contract related to two shipbuilding contracts); Gard Marine and Energy Ltd v Tunnicliffe [2010] EWCA Civ 1052, [2011] 2 All ER (Comm) 208, [39]-[45] (reinsurance); Star Reefers Pool Inc v JFC Group Ltd [2011] EWHC 339 (Comm), [2011] 2 Lloyd's Rep 215, [23]-[24] (guarantee related to a charterparty); Stonebridge Underwriting Ltd v Ontario Municipal Insurance Exchange [2010] EWHC 2279 (Comm), [2010] 2 CLC 349, [35] (reinsurance); Golden Ocean Group Ltd v Salgaocar Mining Industries Pvt Ltd [2012] EWCA Civ 265, [2012] 1 WLR 3674, [45], [49] and [55] (guarantee and warranty of authority related to a charterparty); Alliance Bank JSC v Aquanta Corp [2012] EWCA Civ 1588, [2013] 1 All ER (Comm) 819, [54] (implied indemnity related to a guarantee); Pathfinder Minerals Plc v Veloso
} 
only operate if one or more network contracts are expressly ${ }^{39}$ subject to one and the same national law and does not allow the content of potentially applicable national laws to be taken into account.

But there are at least two problems with the choice of a national law to govern network relations. ${ }^{40}$ First, even if the parties choose - either expressly or tacitly - one national law to govern all bilateral contracts that form a network or network-related issues, there is a possibility that another law (or laws) will be applied on an overriding basis. ${ }^{41}$ This issue is addressed in sub-section IV.C below. Secondly, it is unclear whether network-related issues can be separated from other issues and subjected to one national law. Article 3(1) of Rome I allows the parties to split the applicable law (dépeçage). ${ }^{42}$ However, according to the Giuliano-Lagarde Report on the Rome Convention, the choice of more than one law to a contract is allowed only if 'logically consistent, i.e. it must relate to elements in the contract which can be governed by different laws without giving rise to contradictions'. ${ }^{43}$ While network-related issues appear capable of being governed by different laws without giving rise to logical inconsistencies, this matter has not been authoritatively decided and is therefore inherently uncertain.

[2012] EWHC 2856, [46] (sale of shares in relation to an equity funding agreement); BAT Industries Plc $v$ Windward Prospects Ltd [2013] EWHC 4087 (Comm), [2014] 2 All ER (Comm) 757, [74] (contract for transfer of legal defence in New York litigation and contract for execution of settlement agreement). Compare Gan Insurance Co Ltd v Tai Ping Insurance Co Ltd [1999] 2 All ER (Comm) 54 (CA) (reinsurance); Tonicstar Ltd (Operating as Lloyd's Syndicate 1861) v American Home Assurance Co [2004] EWHC 1234 (Comm), [2012] 1 CLC 271, [10] (reinsurance) (in these two cases, there was no implied choice that would achieve the unity of applicable law). See further CSA Okoli, 'The Significance of the Doctrine of Accessory Allocation as a Connecting Factor under Article 4 of the Rome I Regulation' (2013) 9 JPIL 449; Penades Fons ibid, 256-7 and 268-73.

${ }^{39}$ Giuliano-Lagarde Report (n 35), 17. But see Golden Ocean Group Ltd v Salgaocar Mining Industries Pvt Ltd ibid (choice of law in a contract was implied on the basis of an implied choice of law in a related contract).

${ }^{40}$ Similarly, Cafaggi and Clavel (n 10), 213.

${ }^{41}$ See Arts 9 and 12(2) Rome I.

${ }^{42}$ The third sentence of Art 3(1) provides: 'By their choice the parties can select the law applicable to the whole or to part only of the contract.'

${ }^{43}$ Giuliano-Lagarde Report (n 35), para 4 of the comment of Art 3. 


\section{Choice of law by the default rules}

Where the parties have not chosen a national law to govern a bilateral contract that forms part of a network, in the majority of cases it will be necessary to resort to the general default choice-of-law rules of Article 4 of Rome I. The structure of this Article is as follows. On the one hand, there are fixed choice-of-law rules that determine the governing law for a number of nominate contracts and other contracts with an identifiable characteristic performance. ${ }^{44}$ There is also an escape clause that allows a departure from the law designated by the fixed choice-of-law rules in favour of the law of the country that is manifestly more closely connected with the contract in question. If the contract is not one of the nominate contracts for which a specific choice-of-law rule is provided or has elements of two or more such nominate contracts, and if its characteristic performance cannot be identified, the applicable law will be determined through the direct application of the principle of the closest connection.

It is important to note for the purposes of the present discussion that two of the nominate contracts for which specific choice-of-law rules are provided are typical network contracts. According to Article 4(1)(e), a franchise contract is governed by the law of the franchisee's habitual residence. Similarly, a distribution contract is governed by the law of the distributor's habitual residence pursuant to Article 4(1)(f). Of importance are also the rules for sales and services contracts, which subject these contracts to the law of the country of the seller's/service provider's habitual residence. ${ }^{45}$

\footnotetext{
44 For the theory of characteristic performance see Giuliano-Lagarde Report (n 35), 19; K Lipstein, 'Characteristic Performance - A New Concept in the Conflict of Laws in Matters of Contract for the EEC' (1981) 3 Northwestern Journal of International and Business Law 402; HUJ d'Oliveira, "'Characteristic Obligation" in the Draft EEC Obligation Convention' (1977) 25 AJCL 303.

45 Art 4(1)(a) and (b) Rome I. For the distinction between sales and services contract see Case C-381/08 Car Trim v KeySafety Systems [2010] ECR I-1255 (on the application of what is now Art 7(1)(b) Brussels I Recast to a long-term supply contract between an Italian manufacturer of air bag systems and a German manufacturer of
} 
The default choice-of-law rules raise a number of questions. First, why are franchise and distribution contracts specifically mentioned in Article 4(1)? Why are there no specific choice-of-law rules for other typical network contracts, such as commercial agency contracts, construction contracts etc? Secondly, why is the habitual residence of the franchisee/distributor adopted as the crucial connecting factor? Thirdly, and most importantly, is Article 4 as a whole capable of leading to network-friendly outcomes?

The proposal for Rome I offers the following explanation for the origin of the specific choice-of-law rules for franchise and distribution contracts: 'Regarding the solutions for the different categories of contracts, only those proposed [for franchise and distribution contracts] have come up for discussion and prompted court decisions in the Member States in relation to determination of the characteristic performance.' ${ }^{46}$ The specific choice-of-law rules for franchise and distribution contracts were, therefore, introduced in order to enhance legal certainty with respect to these two types of contract that were perceived as particularly problematic. There are no special rules for other typical network contracts, which are therefore governed by the law of the country of the habitual residence of the party who provides the characteristic performance. ${ }^{47}$ Since the characteristic performance will not be identifiable in many cases of network contracts, the applicable law will often be determined by the direct application of the principle of the closest connection.

There is a degree of confusion with regard to the reasons for according the habitual residence of the franchisee/distributor the status of the crucial connecting factor. According to the proposal for Rome I: 'The solutions are based on the fact that Community law seeks to

components); Case C-9/12 Corman-Collins SA v La Maison du Whiskey SA ECLI:EU:C:2013:860, [2014] QB 431 (on the application of what is now Art 7(1) Brussels I Recast to a distribution agreement).

${ }^{46}$ (n 32), 6. For diverging case law on the determination of the characteristic performance of franchise and distribution contracts see Garcia Gutierrez (n 10), 234-6; Ancel (n 10), 223-6.

${ }^{47}$ See Recital 19 Rome I which states that, in the case of a contract consisting of a bundle of rights and obligations capable of being categorized as falling within more than one of the specified types of contract, the characteristic performance of the contract should be determined having regard to its centre of gravity. 
protect the franchisee and the distributor as the weaker parties. ${ }^{48}$ But this explanation is not entirely satisfactory. A feature of contractual networks is that they create a set of complex relations where the interaction, interdependence and cooperation of all network members is crucial. As the theoretical model of symbiotic contracts demonstrates, ${ }^{49}$ both franchise and distribution contracts are characterised by the existence of double, cross-over principal and agent relations. This leads to the situation where franchisor and franchisee (as well as manufacturer and distributor) are dependent on each other for the success of the network. Although it is true that in many franchise and distribution networks the franchisor and the manufacturer, as network hubs, enjoy a position of power and domination, this is by no means the case for all such networks. ${ }^{50}$ Indeed, this explanation for adopting the habitual residence of the franchisee/distributor as the crucial connecting factor is not mentioned in the recitals of Rome I. Furthermore, scholars who have written about the default choice-of-law rules of Article 4(1) do not accept the rationale of protection as the sole explanation, but also advance the argument that the adoption of these connecting factors leads to the application of the law of the country most affected by the performance of franchise and distribution contracts. ${ }^{51}$ This leads us to the third question, namely whether Article 4 as a whole is capable of leading to network-friendly outcomes.

The focus of the fixed choice-of-law rules of Article 4 is on discrete, bilateral contractual relations. This narrow perspective limited the options of the drafters of Rome I to the laws of habitual residences of the two parties to such a relation. Consequently, the fact that a contractual relation might form part of a contractual network was not sufficiently taken into account during the drafting of the fixed choice-of-law rules. This is confirmed by the

\footnotetext{
48 (n 32), 6.

${ }^{49}$ See text accompanying $\mathrm{n} 17$ above.

${ }^{50}$ See WL Killion, 'The Modern Myth of the Vulnerable Franchisee: The Case for a More Balanced View of the Franchisor-Franchisee Relationship' (2008) 28 Franchise Law Journal 23.

51 Ancel (n 10), 226-7; Garcia Gutierrez (n 10), 238-40; M McParland, The Rome I Regulation on the Law Applicable to Contractual Obligations (OUP, 2015), [10.236] (but see [10.224]).
} 
quote from the proposal for Rome I concerning the origin of the specific choice-of-law rules for franchise and distribution contracts. ${ }^{52}$ Since the determination of the characteristic performance for these two types of contract had proven problematic under the Rome Convention, the drafters of Rome I aimed to introduce legal certainty in the choice-of-law process by giving preference to the habitual residence of the franchisee/distributor over that of the franchisor/manufacturer. Nothing is said - either in the proposal for Rome I or in the recitals of Rome I - about the network context in which these two types of contract typically operate. But the focus on discrete, bilateral contractual relations is unsuitable for contractual networks because it disregards their organisational, company-like features and the fact that the network as a whole is more than the sum of its constituent parts and bilateral contractual relations entered among them. The consequence of the focus on discrete, bilateral contractual relations is that transnational contractual networks are routinely subjected to the regulatory authority of multiple States, which creates the risk of conflict and contradiction. The only exception seems to be provided by Article 4(1)(h) dealing with certain financial agreements which emphasises the need for multiple contracts to be 'governed by a single law'. ${ }^{53}$

Can the escape clause of Article 4(4) be used to achieve the desired unity of applicable law in situations where the fixed choice-of-law rules lead to the fragmentation of the network? In order to answer this question, it is useful to refer again to the recent empirical study conducted by Penades Fons, who concludes that the flexibility inherent in the escape clause has been and can be legitimately used to balance the multiple policy issues generated by international commercial transactions. ${ }^{54}$ There are strong reasons why European law, including European private international law, should protect and enhance the efficiency of transnational contractual networks. Therefore, the use of the escape clause as a tool for

\footnotetext{
$52 \mathrm{n} 46$ above.

${ }^{53}$ See also Recital 29.

54 (n 37).
} 
achieving network-friendly outcomes is justified. ${ }^{55}$ This is supported by Recital 20 of Rome I, which demonstrates that the drafters of this instrument had envisaged utilising the escape clause for the purpose of achieving the unity of applicable law. In applying the escape clause, 'account should be taken, inter alia, of whether the contract in question has a very close relationship with another contract or contracts'. ${ }^{56}$ Furthermore, the CJEU has confirmed in Haeger \& Schmidt GmbH v Mutuelles du Mans assurances IARD (MMA IARD) and others ${ }^{57}$ that in applying the escape clause 'the presence of a close connection between the contract in question with another contract or contracts which are, as the case may be, part of the same chain of contracts' is to be taken into account.

An example of how the escape clause can be used to achieve network-friendly outcomes is provided by the leading English case on choice of law for letters of credit, Bank of Baroda v Vysya Bank, ${ }^{58}$ decided under the Rome Convention. Here, the underlying contract for the sale of goods was between an Irish seller, acting though its London office, and an Indian buyer. The buyer had contracted with an Indian bank (Vysya) to issue a letter of credit. Vysya, in turn, contracted with another Indian bank (Baroda) for the latter to confirm the letter of credit. The addition and honouring of the confirmation of the credit was to be

\footnotetext{
55 Similarly, S Atril, 'Choice of Law in Contract: The Missing Pieces of the Article 4 Jigsaw' (2004) 53 ICLQ 549, in particular 558-9; R Fentiman, 'Commercial Expectations and the Rome Convention' (2002) 61 CLJ 50; R Fentiman, 'Choice of Law in Europe: Uniformity and Integration' (2008) 82 Tulane Law Review 2021, 2048; R Fentiman, 'The Significance of the Closest Connection' in J Ahern and W Binchy (eds), The Rome II Regulation on the Law Applicable to Non-Contractual Obligations (Leiden: Martinus Nijhoff Publishers, 2009) 85, 94-7; R Fentiman, International Commercial Litigation (OUP, 2010), [4.108], [4.110]-[4.121]. See also Ministry of Justice, 'Rome I - Should the UK Opt In', Consultation Paper CP05/08 of 2 April 2008, [54] ('in the context of related contracts ... it is of commercial importance for a single law to be applied to the whole transaction rather than having different laws applying to each of the component parts of the transaction', emphasis added).

56 See also Recital 21 which refers to the existence of related contracts as a relevant factor for the direct application of the principle of the closest connection.

${ }^{57}$ Case C-305/13, ECLI:EU:C:2014:2320, [49].

58 [1994] 2 Lloyd's Rep 87 (QB). Other leading English cases on choice of law for letters of credit include Offshore International SA v Banco Central SA [1977] 1 WLR 399 (QB); Power Curber International Ltd v National Bank of Kuwait SAK [1981] 1 WLR 1233 (CA); European Asian Bank AG v Punjab and Sind Bank [1981] 2 Lloyd's Rep 651 (QB); Bank of Credit and Commerce Hong Kong Ltd v Sonali Bank [1995] 1 Lloyd's Rep 227 (QB); Marconi Communications International Ltd v Pt Pan Indonesia Bank TBK [2005] EWCA Civ 422, [2007] 2 Lloyd's Rep 72. See also C Hare, 'The Rome Convention and Letters of Credit' [2005] LMCLQ 417; CGJ Morse, 'Letters of Credit and the Rome Convention' [1994] LMCLQ 560.
} 
effected in England, through the confirming bank's London office. Letters of credit give rise to a number of autonomous contracts between different parties that constitute a 'mini' contractual network. In Baroda v Vysya, the court considered four contractual relationships: 1) the contract between the buyer and the issuing bank; 2) the contract between the issuing bank and the confirming bank; 3) the contract between the confirming bank and the seller; and 4) the contract between the issuing bank and the seller. The confirming bank had paid the seller in England and sought reimbursement from the issuing bank. After the issuing bank had refused to pay, the confirming bank commenced proceedings in England. The issue of the applicable law was crucial because the claimant argued that the English courts had jurisdiction because the contract between it and the issuing bank was governed by English law. ${ }^{59}$

The court found that the choice-of-law rule of Article 4(2) of the Rome Convention, which was based on the theory of characteristic performance, pointed to the application of Indian law to relationships 1) and 4) and to the application of English law to relationships 2) and 3). After noting that this situation involves a 'wholly undesirable multiplicity of potentially conflicting laws', ${ }^{60}$ Mance J inquired whether the escape clause of Article 4(5) of the Rome Convention could lead to the unity of applicable law. In his view:

In the present case the application of Article 4(2) would lead to an irregular and subjective position where the governing law of a letter of credit would vary according to whether one was looking at the position of the confirming or the issuing bank. It is of great importance to both beneficiaries and banks concerned in the issue and operation of international letters of credit that there should be clarity and simplicity in

\footnotetext{
${ }^{59}$ See para 3.1(6)(c) Civil Procedure Rules Practice Direction 6B.

${ }^{60}$ [1994] CLC 41 (QB), 48.
} 
such matters. Article 4(5) provides the answer. The Rome Convention was not intended to confuse legal relationships or to disrupt normal expectations ...

The present situation provides in my judgment a classic demonstration of the need for and appropriateness of Article 4(5). ${ }^{61}$

The outcome was that the letter of credit was governed by the same law, English law, as between the banks and the beneficiary and each of the banks. ${ }^{62}$

But the escape clause of Article 4(4) of Rome I is a blunt tool that cannot routinely lead to network-favourable outcomes. The main reason is that it is supposed to operate in exceptional circumstances only, where it is clear from all the circumstances of the case that the contract is manifestly more closely connected with a country other than that indicated by the fixed choice-of-law rules. ${ }^{63}$ The fact that the contract in question forms part of a network is unlikely in and of itself to be enough to trigger the application of the escape clause. Moreover, the escape clause does not allow an issue-by-issue choice-of-law analysis and only takes into account the territorial connections that the contract in question has with different jurisdictions. The fact that a certain issue - but not the contract as a whole - is manifestly

\footnotetext{
${ }^{61}$ Ibid, 49.

${ }^{62}$ Other English cases on the use of the escape clause to determine the applicable law of related contracts include Lincoln National Life Insurance Co v Employers Reinsurance Corp [2002] EWHC 28 (Comm), [2002] Lloyd's Rep I.R. 853, [23]-[25] (reinsurance); Emeraldian Ltd Partnership v Wellmix Shipping Ltd (n 38), [171] (guarantee related to a charterparty); Gard Marine and Energy Ltd v Tunnicliffe (n 38), [46]-[47] (reinsurance); British Arab Commercial Bank Plc v Bank of Communications [2011] EWHC 281 (Comm), [2011] 1 Lloyd's Rep 664, [32]-[35] (counter-guarantee); Golden Ocean Group Ltd v Salgaocar Mining Industries Pvt Ltd (n 38), [49]-[54] (warranty of authority related to a charterparty); Alliance Bank JSC v Aquanta Corp (n 38), [54] (implied indemnity related to a guarantee); BAT Industries Plc v Windward Prospects Ltd (n 38), [74] (contract for transfer of legal defence in New York litigation and contract for execution of settlement agreement). Compare Credit Lyonnais v New Hampshire Insurance Co Ltd [1997] CLC 909 (CA) (insurance; the applicable law was determined under the choice-of-law rules of the Insurance Companies Act 1982 which were influenced by the Rome Convention); Samcrete Egypt Engineers and Contractors SAE v Land Rover Exports Ltd [2001] EWCA Civ 2019, [2002] CLC 533 (guarantee related to a distribution contract); Caledonia Subsea Ltd $v$ Microperi Srl 2002 SLT 1022 (sub-contracting); Dornoch Ltd v Mauritius Union Assurance Co Ltd [2006] EWCA Civ 389, [2006] 2 All ER (Comm) 385, [40]-[43] (reinsurance) (in these four cases, the escape clause was not (specifically) used to achieve the unity of applicable law). See further Okoli (n 38); Penades Fons (n 37), 256-7 and 268-73.

${ }^{63}$ See Z Tang, 'Law Applicable in the Absence of Choice - The New Article 4 of the Rome I Regulation' (2008) 71 MLR 785, 797-800.
} 
more closely connected with a particular country cannot trigger the application of the escape clause. The content of potentially applicable laws, i.e. whether or not they have adequate rules for network-related issues, is irrelevant for the purposes of applying the escape clause. These are also the reasons why the direct application of the principle of the closest connection (in situations where the contract is not one of the nominate contracts for which a specific choiceof-law rule is provided or has elements of two or more such nominate contracts, and its characteristic performance cannot be identified) is unlikely to lead routinely to networkfavourable outcomes.

There are several ways in which Article 4 of Rome I could be made more suitable for dealing with contractual networks. The main problem with this Article is that it focuses on discrete, bilateral contractual relations. The organisational, company-like features of contractual networks are not sufficiently taken into account. It is important to note here that relations within corporations are typically subjected to one law only. The unity of applicable law for company law issues is achieved in some countries through the application of the law of the company's seat and in others through the application of the law of the company's place of incorporation. ${ }^{64}$ Rome I should give more weight to the organisational aspects of contractual networks. Networks that are organised in a hub and spokes pattern, in particular, could be subjected by default to the law of the country of the network centre. But there should also be enough flexibility to allow the application, where appropriate, of the law of the country of the network node to accommodate the flexibility that is inherent in networks. This would require relatively minor changes to Rome I, e.g. the amendment of the choice-of-law rules for franchise and distribution contracts that would make the law of the habitual residence of the franchisor/distributor applicable by default and an introduction of analogous rules for other kinds of contracts that typically form networks that are organised in a hub and

\footnotetext{
${ }^{64}$ See S. Rammeloo, Corporations in Private International Law: A European Perspective (Oxford: OUP, 2001).
} 
spokes pattern (e.g. commercial agency networks). Furthermore, the escape clause could be made more flexible by either omitting the requirement for a 'clear' 'manifestly' closer connection in cases involving contractual networks ${ }^{65}$ or at least by clarifying in the Recitals that the escape clause should be used flexibly not only in the context of connected contracts entered into between the same two parties, but also in the context of connected contracts entered into between different parties within a contractual network. ${ }^{66}$ This could be combined with a rule that would allow the splitting of the applicable law (dépeçage) in appropriate circumstances (e.g. where it is appropriate to have some issues governed by the law of the network centre and other issues by the law of the network node). ${ }^{67}$ However, even with these changes, the general default choice-of-law rules of Rome I would struggle to routinely lead to network-favourable outcomes for many types of contractual networks, in particular those organised in a chain or mixed pattern.

Another way of improving Article 4 would be to accept the proposal put forward by Cafagi and Clavel for a functional choice of law. ${ }^{68}$ Under this proposal, the escape clause should be used, in the context of contractual networks, to select the law whose content is, from a functional point of view, the most consistent with the network purpose. This methodology would take into account not only the various territorial contacts that a network contract has with different jurisdictions, but also the content of potentially applicable laws with respect to network-related issues. However, this proposal clashes with the orthodox view that only territorial connections between a contract and different jurisdictions can be taken

\footnotetext{
${ }^{65}$ See the escape clause of Art 4(5) of the Rome Convention.

${ }^{66}$ It is unclear whether the existing Recital 20 of Rome I is supposed to apply only in the former or also in the latter situation.

${ }^{67}$ For example, Art 4(1) of the Rome Convention, after stating that the contract shall be governed by the law of the country with which it is most closely connected, provided as follows: 'Nevertheless, a severable part of the contract which has a closer connection with another country may by way of exception be governed by the law of that other country.'

68 (n 10), 226, 228, 243-4.
} 
into account under the escape clause ${ }^{69}$ and is therefore, despite its merits, unlikely to gain much support.

\title{
B. Interaction between the General and Special Choice-of-Law Rules of Rome I and
}

\author{
Contractual Networks
}

Some contractual networks engage simultaneously the general and special choice-of-law rules of Rome I. In a credit card transaction, ${ }^{70}$ for example, relations between the consumer, on the one hand, and the retailer and the lender, on the other, will often fall within the scope of the special private international rules for consumer contracts. ${ }^{71}$ Relations between the retailer and the lender fall within the scope of the general rules. In temporary agency work, ${ }^{72}$ to take another example, relations between the worker, on the one hand, and the agency and the enduser, on the other, usually fall within the personal scope of some pieces of labour legislation and also within the scope of the special private international law rules for employment

\footnotetext{
${ }^{69}$ See Case C-64/12 Anton Schlecker v Melitta Josefa Boedeker, the Opinion of Advocate General Wahl, ECLI:EU:C:2013:241, [2014] QB 320, [21].

${ }^{70}$ Heermann mentions a credit card transaction as an example of a 'mini' contractual network: PW Heermann, 'The Status of Multilateral Synallagmas in the Law of Connected Contracts' in Amstutz and Teubner (eds) (n 11) 103. It should be noted that Teubner's concept of connected contracts, through which he conceptualises in legal terms contractual networks, has its root in Art 358 of the German Civil Code (BGB) which is concerned with the particular problems of consumers' withdrawal from contracts entered into using a credit arrangement with the bank and the retailer.

${ }^{71}$ The personal scope of the special choice-of-law rules for consumer contracts is determined by Art 6 of Rome I. These rules apply only where the professional (a) pursues his commercial or professional activities in the country where the consumer has his habitual residence, or (b) by any means, directs such activities to that country or to several countries including that country, and the contract falls within the scope of such activities. There is also a list of situations in which the application of Art 6 is excluded.

${ }^{72}$ Collins advances strong reasons to treat the parties to a temporary agency work relation as forming part of a network: Collins (n 2), 7, 59-62 and 65.
} 
contracts. ${ }^{73}$ Relations between the agency and the end-user fall within the scope of the general rules.

Can the simultaneous application of the general and the special choice-of-law rules lead to network-favourable outcomes? The special rules are characterised by the fact that they restrict party autonomy and are based on connecting factors that reflect the peculiar features of the covered contractual relations. For example, in contracts involving consumers and employees, party autonomy is limited with the aim of protecting the weaker party. ${ }^{74}$ Thus, the professional and the employer cannot deprive the weaker party, by means of choice of law, of the protection afforded to the latter by the mandatory rules of the law applicable in the absence of choice. The law applicable in the absence of choice for consumer contracts is determined by an inflexible choice-of-law rule, which points to the law of the consumer's habitual residence. ${ }^{75}$ Employment contracts are governed by the law of the habitual place of work, although there is a possibility of applying the law of another country that is more closely connected with the contract. ${ }^{76}$

A consumer typically enters into contract with the retailer and the lender in the country where he or she is habitually resident. In this situation, the special choice-of-law rules will lead to the application of the same law to relations between the consumer and the other two parties. Since the gravity of this 'mini' contractual network is clearly in the country of the consumer's habitual residence, there is a strong reason to apply the escape clause in cases where the retailer and the lender have not exercised their party autonomy in order to achieve the application of the law of the country of the consumer's habitual residence also to relations

\footnotetext{
${ }^{73}$ The special choice-of-law rules for employment contracts apply to 'individual employment contracts': Art 8 . For an examination of the personal scope of these rules see U Grušić, The European Private International Law of Employment (CUP, 2015), Ch 3 and Case C-47/14 Holterman Ferho Exploitatie BV v Spies von Büllesheim ECLI: EU:C:2015:574, [2015] IL Pr 44.

${ }^{74}$ See Recital 23 Rome I.

${ }^{75}$ Art 6 Rome I.

${ }^{76}$ Art 8 Rome I.
} 
between the retailer and the lender. However, there are situations where relations between the consumer and the other two parties do not fall within the scope of the special choice-of-law rules for consumer contracts, in which case the relation(s) outside the scope of the special rules engage the application of the general choice-of-law rules. In these situations, and for the reasons mentioned in the previous sub-section, the choice-of-law rules of Rome I will struggle to routinely achieve the desired unity of applicable law.

The special choice-of-law rules for employment contracts seem incapable of leading systematically to the unity of applicable law whenever a worker who is hired by an agency in one country is posted to work for end-users in different countries. In this situation, the special choice-of-law rules are likely to lead to the fragmentation of the network, ${ }^{77}$ with all the risk of conflict and contradiction that this creates.

\section{Rome I, Overriding Mandatory Provisions and Contractual Networks}

Overriding mandatory provisions are defined as provisions the respect for which is regarded as crucial by a country for safeguarding its public interests, such as its political, social or economic organisation, to such an extent that they are applicable to any situation falling within their scope, irrespective of the law otherwise applicable to the contract. ${ }^{78}$ Many provisions concerning contractual networks fall into this category. For example, the CJEU has held that the rules of the Commercial Agents Directive, which regulate certain aspects of

\footnotetext{
${ }^{77}$ For the application of Art 8 of Rome I to posting of workers abroad by employment agencies see Grušić (n 73), section 5.3. See also ibid, Ch 8, on the posting of workers in Europe.

${ }^{78}$ Art 9(1) Rome I.
} 
commercial agency networks, are of this nature. ${ }^{79}$ So are potentially many rules on franchise and distribution networks ${ }^{80}$ and construction contracts. ${ }^{81}$ Furthermore, 'mini' contractual networks such as credit card transactions and temporary agency work involve relations that often fall within the scope of consumer and employment protection legislation, which is typically considered as overridingly mandatory in many Member States. ${ }^{82}$

If a legal relationship falls within the scope of an overriding mandatory provision, that provision will typically mandate its application regardless of the law that governs the relationship under the choice-of-law rules. Rome I allows the application of the overriding mandatory provision of the law of the forum and, under certain conditions, of the overriding mandatory provisions of the country of performance. ${ }^{83}$ However, if a legal relationship takes place within the EU internal market, the overriding application of mandatory rules is allowed only if it is in accordance with substantive European law. ${ }^{84}$ In other words, the overriding application of mandatory rules that represents a restriction of a fundamental economic freedom is allowed only if it is non-discriminatory, justified and proportionate.

\footnotetext{
${ }^{79}$ Case C-381/98 Ingmar GB Ltd v Eaton Leonard Technologies Inc [2000] ECR I-9305. See also Case C184/12 United Antwerp Maritime Agencies (Unamar) NV v Navigation Maritime Bulgare ECLI:EU:C:2013:663, [2014] 1 Lloyd's Rep 161.

${ }^{80}$ See, for example, statutes enacted in the United States addressing what has been perceived as abuses of the relations of power and domination in network contracts in certain market sectors: EU Federal Trade Commission Rule: Disclosure Requirements and Prohibitions Concerning Franchising and Business Opportunity Ventures 16 CFR pt 436; California Franchise Investment Law (1971); Delaware Franchise Security Law (1970); New Jersey Franchise Practices Act (1971); US Petroleum Marketing Practices Act 15 USC ss 2801-2806; US Automobile Dealers Day in Court Act 15 USC ss 1221-1225.

${ }^{81}$ See the decisions of the French Cour de cassation (Ch Mixte, 30 November 2007, pourvoi n 06-14006; Cass Civ 3, 30 January 2008, pourvoi n 06-14641; Cass Civ 3, 8 April 2008 pourvoi n 07-10763), holding that the French law No 75-1334 of 1975, which recognises an action directe among non-contracting network members, is an overriding mandatory provision whenever the contract is for the construction of an immoveable in France. See also P Piroddi, 'The French Plumber, Subcontracting, and the Internal Market' (2008) 10 YBPIL 593 and P. Roscher, 'Forty Years On: French Law on Sub-Contracting' (2015) 32 International Construction Law Review 44.

${ }^{82}$ For the overriding nature of English consumer and employment protection legislation see: Office of Fair Trading v Lloyds TSB Bank plc and others [2007] UKHL 48, [2008] 1 AC 316 and Serco Ltd v Lawson; Botham (FC) v Ministry of Defence; Crofts v Veta Ltd [2006] UKHL 3, [2006] 1 All ER 823; for a critical view of these cases see C Bisping, 'Avoid the Statutist Trap: The International Scope of the Consumer Credit Act' (2012) 8 JPIL 35 and Grušić (n 73), Ch 6.

${ }^{83}$ Arts 9(2) and 9(3) Rome I.

${ }^{84}$ See M Fallon and J Meeusen, 'Private International Law in the European Union and the Exception of Mutual Recognition' (2002) 4 YBPIL 37. See also Case C-184/12 United Antwerp Maritime Agencies (Unamar) NV $v$ Navigation Maritime Bulgare (n 79).
} 
The overriding application of mandatory rules will sometimes contribute positively to the regulation of transnational contractual networks, in particular where a dominant network member imposes on other network members the application of a law that is not particularly closely connected with the bilateral relations within the network and does not take into account the network purpose. But in the majority of cases the existence of provisions that apply to networks in an overriding manner will increase the risk of conflict and contradiction by creating or exacerbating the problem of application of multiple laws to transnational contractual networks. Accordingly, the potential undermining of the objectives of network regulation should be one of the factors to be taken into account when deciding on the application of overriding mandatory rules.

\section{CHOICE OF LAW AND INTERNAL ASPECTS OF NETWORKS 2: RELATIONS BETWEEN NETWORKS MEMBERS NOT IN A DIRECT CONTRACTUAL RELATION}

Relations between network members who are not directly connected by bonds of contract are classified as non-contractual in European private international law, thus falling within the scope of Rome II. This has been confirmed in a number of cases concerning the scope of application of Articles 7(1) and 7(2) of the Brussels I Recast and their predecessors, starting with the case of Jakob Handte that involved an action directe under French law between subcontractors. $^{85}$

Rome II lays down a number of choice-of-law rules for different types of noncontractual obligations, namely torts/delicts, unjust enrichment, agency without authority (negotiorum gestio) and pre-contractual liability (culpa in contrahendo). Liability claims

\footnotetext{
${ }^{85}$ (n 27). For a different view see Piroddi (n 10), 322-3.
} 
between network members not bound to one another by express contracts are typically conceived in national legal systems as claims in tort for the compensation of economic loss. Choice-of-law issues raised by such claims fall under the choice-of-law rules for torts of Rome II.

Rome II contains one general choice-of-law rule for torts and a number of special choice-of-law rules for product liability, unfair competition and acts restricting free competition, environmental damage, infringement of IP rights and industrial action. Although there are situations involving transnational contractual networks that may trigger the application of the special choice-of-law rules, the vast majority of networks give rise to relations that fall under the general choice-of-law rule of Article 4, which is the focus of the text that follows.

Article 4 contains two choice-of-law rules and one escape clause. Article 4(1) provides that the law applicable to a non-contractual obligation arising out of a tort is the law of the country in which the damage occurs irrespective of the country in which the event giving rise to the damage occurred and irrespective of the country or countries in which the indirect consequences of that event occur. Article 4(2) further provides that where the person claimed to be liable and the person sustaining damage both have their habitual residence in the same country at the time when the damage occurs, the law of that country shall apply. Finally, there is an escape clause in Article 4(3), which allows the departure from the applicable laws designated by the preceding two provisions in favour of the law of the country that is manifestly more closely connected with the tort in question. In addition, Article 14 provides for party autonomy. The parties are free to choose the applicable law after the event giving rise to the damage has occurred. The parties can also choose the applicable law ex ante, but only if all the parties are pursuing a commercial activity and the agreement is freely negotiated before the event giving rise to the damage occurred. Finally, Article 16 
allows the application of the overriding mandatory provisions of the forum and Article 17 provides that, in assessing a defendant's conduct regard shall be had to rules of safety and conduct in force where the event causing damage occurred.

As is clear from this brief description of the choice-of-law rules for torts of Rome II, the basic scheme adopted by this instrument (party autonomy - general and special choice-oflaw rules - fixed choice-of-law rules and escape clauses - overriding mandatory provisions) is essentially the same as that of Rome I. So are the fundamental problems created by the State-centricity and the focus on discrete, bilateral relations in a network and territoriality of the two instruments. This sub-section will highlight some problems that are peculiar to Rome II, such as the determination of the 'country in which the damage occurs' in the case of economic torts and the application of the escape clause of Article 4(3).

Relations between network members not bound by express contracts are classified as non-contractual, potentially giving rise to claims for compensation for economic loss. According to Article 4(1), the law applicable to such non-contractual relations is the law of the country in which the direct damage occurs. The main problem with the application of Article 4(1) in the context of contractual networks is the fact that the place in which economic loss occurs is 'notoriously hard to locate' ${ }^{86}$ According to Lehmann, who dealt with this issue through the examination of five case studies (economic loss for misleading information; false prospectuses and financial statements; mismanagement of assets; breach of statutory duties; inducing an unfavourable contract), the location of economic loss should be determined differently for the following types of loss: loss of a distinguishable and locatable asset; loss which involves a wilful transfer of money by the victim to another account; loss which includes a fortuitous transfer of funds through a number of different accounts; cases where the loss cannot be attributed to only one country; and the loss caused by an unfavourable

\footnotetext{
${ }^{86}$ Lehmann (n 27), 531.
} 
contract. ${ }^{87}$ Even without describing in detail the application of Article 4(1) to these types of economic loss, it should be clear that the law applicable to non-contractual relations within a network is hard to ascertain and, furthermore, that there are no guarantees that Article 4(1) will lead to the application of a law that is strongly connected with the non-contractual relation in question. An important aspect of the application of the general choice-of-law rule of Article 4, in the context of contractual networks, is therefore the operation of the escape clause.

The escape clause of Article 4(3) of Rome II is worded identically to that of Article 4(4) of Rome I. Accordingly, everything that is mentioned in sub-section IV.A.2 above is also of relevance here. But there is one difference between the two Articles, namely the fact that the escape clause of Article 4(3) of Rome II expressly mentions one example of a manifestly closer connection that is relevant for the present discussion. It is stated that a manifestly closer connection 'might be based in particular on a pre-existing relationship between the parties, such as a contract, that is closely connected with the tort/delict in question'. This rule is known as the accessory choice-of-law rule and is designed to lead to the unity of applicable law in cases that give rise to concurrent causes of action in choice-of-law. ${ }^{88}$ The accessory choice-of-law rule is designed for situations where contractual and non-contractual obligations arise simultaneously between two parties. But the underlying objective of unity of applicable law applies equally to transnational contractual networks that give rise to a host of related contractual and non-contractual relations between different parties ${ }^{89}$ and this is something that could be clarified in the recitals of Rome II. In any event, due to the

\footnotetext{
${ }^{87}$ Ibid, 541-9.

${ }^{88}$ See PE Nygh, Autonomy in International Contracts (Oxford: Clarendon, 1999), 240-7.

${ }^{89}$ But see A Briggs, Private International Law in English Courts (OUP, 2014), [8.105] ('In more complex cases, of course, which arise where the commercial relationship comprises a number of linked contracts and a number of associated contracting parties, this analysis may be more difficult and not for the faint-hearted. It is submitted, however, that the court should start first from principles. If the gist of the tort, as pleaded, could just as easily have been put forward as a claim for breach of a particular contract, it is not helpful to look beyond it to the broader contractual matrix to complicate the application of Article 4(3).')
} 
limitations inherent in the escape clauses of the two Rome Regulations, namely the fact that they are designed to operate in exceptional circumstances only, that they do not allow an issue-by-issue choice-of-law analysis and that they do not allow the taking into account of the content of potentially applicable laws, it cannot be expected that network-favourable outcomes will be routinely achieved. ${ }^{90}$

\section{INTERNATIONAL LITIGATION AND EXTERNAL ASPECTS OF NETWORKS}

A key problem concerning contractual networks relates to the responsibility for harm caused by the network to third parties. The question is whether, in situations where a third party suffers harm as a result of the activities of a network, that third party can obtain compensation not only from the network member to which it was directly exposed but also from the network as a whole or at least from the network members who participated in the generation and realisation of risk. Although scholars have been pleading for more responsibility in external network relations, ${ }^{91}$ national legal systems are slow to impose direct duties between network members not directly exposed to third parties and third party victims. The problem is exacerbated in the context of transnational contractual networks because they are spread across State boundaries, often across several continents, and are connected to multiple laws

\footnotetext{
${ }^{90}$ Muir Watt (n 10) has advanced, at pp 366-7, another solution for achieving network-favourable outcomes in this context. According to her, the existence of reciprocal actions among network participants will induce or enhance cooperation. 'This could perfectly well be attained by means of the method and approach implemented by the 1973 Hague Convention on the law applicable to product liability, now replaced by Rome II Regulation (Article 5). Put simply, the conflict rule ensures the application of a single law in the relation between actors at the two ends of the chain. This approach is particularly fitting because an essential element of the network is that it mandates not to distinguish between contractual and non-contractual relationships among participants, and encourages their equal treatment in terms of the access to rights and allocation of duties.' (footnote omitted)

${ }^{91}$ See Teubner (n 2), Ch 6. See also H Collins, 'Ascription of Legal Responsibility to Groups in Complex Patterns of Economic Integration' (1990) 53 MLR 731; O. De Schutter, 'Extraterritorial Jurisdiction as a Tool for Improving the Human Rights Accountability of Transnational Corporations', available at http://cridho.uclouvain.be/documents/Working.Papers/ExtraterrRep22.12.06.pdf, 45-46.
} 
with potentially conflicting and contradictory contents. The question for private international law is whether, and how, it can help regulate such networks by countering the external risks that they generate.

Reports from different corners of the world of appalling human rights and environmental practices and of breaches of labour and consumer standards by members of transnational contractual networks often fill the headlines. ${ }^{92}$ Much of these violations of human rights, environmental, labour and consumer protection laws are the result of external risks generated by transnational contractual networks. In order to ascertain the role of private international law in countering such risks, this section will focus on cases of alleged gross human rights and environmental violations that have been committed by members of transnational networks. To keep the discussion within manageable bounds, the following text will focus on the cases of this type brought in the UK courts. The focus on the UK is justified because this country is arguably the second leading centre (after the United States) for the litigation of claims brought by oversees victims of alleged gross human rights and environmental violations. Given that most of the rules concerning international litigation in the UK are of European law origin, the following discussion is also relevant for other Member States of the EU.

The cases of alleged gross human rights and environmental violations that have been brought in the UK typically exhibit the following characteristics. Victims, usually from a developing country, suffer an infringement of their fundamental human rights (e.g. right to life, physical and mental integrity, liberty and security, respect for private and family life and home, freedom of expression, freedom of assembly and association, free trial, social and economic rights etc.) or a degradation of their environment, leading to a personal injury or property damage, which is the result of the activities of an overseas subsidiary of a

\footnotetext{
${ }^{92}$ See http://business-humanrights.org/, where many cases have been reported.
} 
transnational corporation. The victims commence proceedings in the UK against the parent company over which the UK courts have adjudicatory jurisdiction, sometimes joining the overseas subsidiary to the proceedings. The claims are typically advanced in tort, e.g. negligence, battery, assault and false imprisonment etc., on the basis that the parent company owed a direct duty of care to the victims or, much less frequently, on the basis of the piercing of the corporate veil that separates the parent and the subsidiary.

More specifically, cases that have been brought in the UK concerned the rights of the victims of asbestos, ${ }^{93}$ uranium, ${ }^{94}$ mercury ${ }^{95}$ and silicosis ${ }^{96}$ poisoning in South African and Namibian mines and factories; the rights of Peruvian environmental protesters who had been allegedly unlawfully imprisoned, tortured and sexually abused by police at a copper mine owned by a local subsidiary of a transnational corporation; ${ }^{97}$ the rights of Colombian farmers against British Petroleum for damage to their land, crops and animals allegedly caused by the construction of an oil pipeline in Colombia; ${ }^{98}$ the rights of victims of fly-tipped toxic waste in Abidjan, Ivory Coast $;{ }^{99}$ the rights of Tanzanian villagers who had been allegedly killed or injured by security guards and police at a mine owned by a local subsidiary of a transnational corporation; ${ }^{100}$ the rights of Cambodian villagers arguably violently evicted from their lands and relocated involuntarily to make room for a sugar plantation against a transnational

\footnotetext{
${ }^{93}$ Lubbe v Cape Plc [2000] 1 WLR 1545 (HL) (on forum non conveniens); Durham v T\&N Plc, Court of Appeal, 01 May 1996, unreported.

${ }^{94}$ Connelly v RTZ Corp Plc (No 2) [1998] AC 854 (HL) (on forum non conveniens).

${ }^{95}$ Ngcobo v Thor Chemicals Holdings Ltd [1995] TLR 579 (CA) (on the striking out of the defendant's notice of appeal against a refusal to stay proceedings); Sithole v Thor Chemicals Holdings Ltd [1999] TLR 110 (CA) (on the setting aside of a default judgment and stay of proceedings).

${ }^{96}$ See Vava v Anglo American South Africa Ltd [2012] EWHC 1969 (QB), [2013] Bus LR D48 and [2013] EWHC 2131 (QB), [2013] Bus LR D65 (both cases concerned the domicile of the defendant for the purposes of the Brussels I Regulation).

${ }^{97}$ See Guerrero v Monterrico Metals Plc [2009] EWHC 2475 (QB) (on disclosure and freezing orders) and [2010] EWHC $3228(\mathrm{QB})$ (on the amendment of particulars of claim).

${ }_{98}^{98}$ See Arroyo v Equion Energia Ltd (Formerly BP Exploration Co (Colombia) Ltd) [2013] EWHC 3173 (TCC) (on permission to include a claim for general damages); see also http://business-humanrights.org/en/bp-lawsuitsre-casanare-colombia.

${ }^{99}$ See Motto v Trafigura Ltd [2011] EWCA Civ 1150, [2012] 1 WLR 657 (on the proportionality of a bill of costs).

${ }^{100}$ See Kesabo v African Barrick Gold Plc [2013] EWHC 4045 (QB) (on costs arising out of an application for an anti-suit injunction).
} 
corporation; ${ }^{101}$ the rights of Nigerian fishermen in relation to oil spills from Shell's TransNiger Pipeline; ${ }^{102}$ and the rights of Zambian villagers in relation to water pollution allegedly caused by a local subsidiary of a transnational corporation. ${ }^{103}$

The mentioned cases exhibit one characteristic of importance for the present discussion. Virtually all the cases concerned transnational organisational networks, i.e. corporate groups. ${ }^{104}$ This is not because transnational contractual networks do not generate significant risks for human rights and the environment. This is arguably because it is very hard, indeed virtually impossible in many cases, for victims of alleged gross violations of human rights and the environment committed overseas by a member of a transnational contractual network to access justice in the UK. ${ }^{105}$ This is for at least two reasons, both of which concern litigation funding. Before proceeding further, it should be noted that such victims are not entitled to legal aid in the UK and typically have to obtain representation on a no-win no-fee basis in order to commence proceedings in this country, given their typical lack of means and the high cost of litigating claims of this type.

Firstly, connections between members of transnational contractual networks are typically looser than those between constituent parts of organisational networks. Consequently, claims that are based on a direct duty of care owed to a third party victim by a

101 http://business-humanrights.org/en/koh-kong-sugar-plantation-lawsuits-re-cambodia\#c86294; M. Mohan, 'The Road to Song Mao: Transnational Litigation from Southeast Asia to the United Kingdom' [2014] AJIL Unbound e-30.

102 http://business-humanrights.org/en/shell-lawsuit-re-oil-spills-bodo-community-in-nigeria.

103 http://business-humanrights.org/en/vedanta-resources-re-water-contamination-zambia.

104 The unusual case of Trafigura is an exception. It did not concern an organisational network or a contractual network. Another exception is the Song Mao litigation where the claimants commenced proceedings against the purchaser of sugar grown on the land arguing that they remained the legal owners of the land and thus the rightful owners of crops grown on it.

${ }^{105}$ For the importance of access to justice see the United National Guiding Principles on Business and Human Rights, available at http://business-humanrights.org/en/un-guiding-principles, in particular principle 25. Compare the German Lidl lawsuit (http://business-humanrights.org/en/lidl-lawsuit-re-working-conditions-inbangladesh) and the French Auchan lawsuit (http://business-humanrights.org/en/auchan-lawsuit-re-garmentfactories-in-bangladesh) where the German and French supermarkets were sued for allegedly misleading advertisements regarding the conditions in which the clothing that they were selling was produced by their suppliers from Bangladesh; see also the German KiK lawsuit commenced in 2015, in which the survivors and families of victims of a fire in a textile factory in Pakistan that resulted in 260 deaths seek compensation from $\mathrm{KiK}$, the factory's main customer (http://business-humanrights.org/en/kik-lawsuit-re-pakistan). 
network member who was not directly exposed to third parties enjoy comparatively little chance of succeeding. In the English law of torts, for example, claims based on a direct duty of care by a parent company to a victim of the activities of a subsidiary can succeed only in truly exceptional circumstances. ${ }^{106}$ Using this line of case law as a benchmark, it can be concluded that the chances of an equivalent claim succeeding against the member of a contractual network not directly exposed to third parties are significantly lower because of the difficulty of demonstrating a sufficient degree of proximity between the alleged tortfeasor and the victim and foreseeability. ${ }^{107}$ As a result, victims of alleged gross violations of human rights and the environment committed overseas by a member of a transnational contractual network will find it very hard to find lawyers in the UK who will take on their case on a nowin no-fee basis.

The second reason why such victims will find it very hard to access justice in the UK concerns the interaction between the recent changes introduced in the system of legal fees by the Legal Aid, Sentencing and Punishment of Offenders Act 2012 and the choice-of-law rules of Rome II. ${ }^{108}$ The changes introduced by the 2012 Act affected the recovery of fees and costs available to claimants, including human rights and environmental claimants. Before the entry into force of this Act on 1 April 2013, claimants were able to recover from defendants full legal costs, success fees and litigation insurance premiums. After this date, claimants cannot recover success fees ${ }^{109}$ and insurance premiums, ${ }^{110}$ but only 'reasonable' costs. ${ }^{111}$ Any success fee is now to be deducted from the damages awarded. Rome II, which applies to

\footnotetext{
${ }^{106}$ Compare Chandler v Cape Plc [2012] EWCA Civ 525, [2012] 1 WLR 3111 with Thompson v Renwick Group Plc [2014] EWCA Civ 635, noted by U Grušić (2015) 74 CLJ 30.

${ }^{107}$ Compare C. van Dam, 'Tort Law and Human Rights: Brothers in Arms. On the Role of Tort Law in the Area of Business and Human Rights' (2011) Journal of European Tort Law 221 and P Rott and V Ulfbeck, 'Supply Chain Liability of Multinational Corporations?' (2015) 23 European Review of Private Law 415, 430-6.

${ }^{108}$ See MD Goldhaber, 'Corporate Human Rights Litigation in Non-US Courts: A Comparative Scorecard' (2013) 3 UC Irvine Law Review 127, 133-4.

${ }^{109} \mathrm{~S} 44(4)$ of the 2012 Act.

${ }^{110} \mathrm{~S} 46(1)$.

${ }^{111} \mathrm{~S} 26(1)$ ('Costs ordered against an individual in relevant civil proceedings must not exceed the amount (if any) which it is reasonable for the individual to pay having regard to all the circumstances').
} 
events giving rise to damage occurring after 11 January $2009,{ }^{112}$ has abolished the old common law choice-of-law rule according to which the amount of damages was always a matter for the law of the forum, i.e. English law. ${ }^{113}$ Under Rome II, the amount of damages is governed by the lex delicti, which is, as a matter of principle, the law of the country in which the damage occurs. ${ }^{114}$ Since the damage in cases brought by victims of alleged overseas gross violations of human rights and the environment typically occurs in a developing country, the amount of damages potentially recoverable in UK courts is now arguably lower than it was before 2009. This fact, coupled with the fact that claimants can only recover from defendants 'reasonable' costs and that any success fee is now to be deducted from the damages awarded, reduces drastically the incentives for lawyers to take on a case under a no-win no-fee arrangement. This is confirmed by Richard Meeran, a leading UK litigator in this area, according to whom these changes are 'a powerful deterrent against claimants' lawyers undertaking these cases'.115

These observations lead to the conclusion that the private international law framework which applies to claims by victims of alleged gross violations of human rights and the environment committed overseas by a member of a transnational contractual network is not well suited to deal with external risks generated by networks and is in an urgent need of change. One way of improving the law is through clarification, ideally at supra-national level, of conditions under which the whole network or at least the network members who participated in the generation and realisation of risk should be liable to third party victims. At the same time, courts could be allowed to apply these rules directly either because the

\footnotetext{
${ }^{112}$ Case C-412/10 Homawoo v GMF Assurances ECLI:EU:C:2011:747, [2012] IL Pr 2.

${ }^{113}$ Wealands $v$ Harding [2006] UKHL 32, [2007] 2 AC 1.

114 Arts 4(1) and 15(c) Rome II. Arts 4(2) (the rule of the common habitual residence of the tortfeasor and the victim) and 4(3) (escape clause) are unlikely to apply.

${ }^{115}$ R Meeran, "Tort Litigation against Multinationals ("MNCs") for Violation of Human Rights: an Overview of the Position outside the US', available at http://businesshumanrights.org/sites/default/files/media/documents/richard-meeran-tort-litigation-against-mncs-7-mar2011.pdf, 15 .
} 
transnational network has subscribed to them ${ }^{116}$ or as the applicable non-state rules of law. In addition, the victim could be given the possibility to choose the applicable law between the law of the place where the harmful event occurs and the law of the place of generation of significant risks. ${ }^{117}$ Finally, one should not forget the importance of adequate rules on litigation funding, either through legal aid or conditional or contingent fees, without which many litigations concerning transnational contractual networks are effectively impossible.

\section{CONCLUSIONS}

This article demonstrates that contractual networks are an economic and sociological phenomenon that raises particular and important regulatory challenges. Given the ubiquity and economic importance of contractual networks, and the fact that their regulation occurs at national level, private international law, in particular European private international law, should take a conscious, active and positive role in their regulation with the aim of protecting and enhancing their efficiency and countering the risks that they create.

The goal of protecting and enhancing the efficiency of transnational contractual networks requires private international law to foster cooperation and coordination in the network. Private international law can achieve this by leading to the unity of applicable law

\footnotetext{
116 This is not a fanciful proposition. Many transnational corporations voluntarily subscribe to various non-state bodies of law that concern corporate social responsibility. See, for example, the UN Guiding Principles on Business and Human Rights, Global Compact (http://www.unglobalcompact.org/), Agenda 21 (http://www.unep.org/Documents.Multilingual/Default.asp?DocumentID=52\&ArticleID=49), the International Labour Organisation Tripartite Declaration of Principles Concerning Multinational Enterprises and Social Policy (http://www.ilo.org/empent/Publications/WCMS 094386/lang--en/index.htm), the Organisation for Economic Co-operation and Development Guidelines for Multinational Enterprises (http://www.oecd.org/daf/inv/mne/) and the ISO 26000 Guidance Standard on Social Responsibility (http://www.iso.org/iso/home/standards/iso26000.htm).

117 Some inspiration can be drawn from Art 7 of Rome II, which lays down choice-of-law rules for environmental damage. For a critical view of Art 7 see U. Grušić, 'International Environmental Litigation in EU Courts: A Regulatory Perspective', forthcoming in (2016) 35 Yearbook of European Law.
} 
governing either all bilateral relations in a network - be they contractual or non-contractual in nature - or network-related issues. The rules of European private international law are ill suited for this task for several reasons. Firstly, the fact that every bilateral relation in a network must be governed by a national law potentially creates the risk of conflict and contradiction whenever a non-state body of law is chosen to govern network relations. Secondly, it is unclear whether the parties can split their relationship by separating networkrelated issues from other issues and subjecting them to one national law; the possibility of dépeçage is definitely excluded where the applicable law falls to be chosen by the default choice-of-law rules. Thirdly, the choice-of-law rules of Rome I and Rome II are focused on discrete, bilateral relations in a network and do not sufficiently take into account the organisational, company-like features of contractual networks. Fourthly, implied choice of law and the escape clauses of the two instruments are blunt tools that cannot routinely lead to network-friendly outcomes because they operate in exceptional circumstances only and do not allow an issue-by-issue choice-of-law analysis and the taking into account of the content of potentially applicable laws. Finally, mandatory rules often affect the choice-of-law process. Although they sometimes contribute positively to the regulation of transnational contractual networks, mandatory rules usually increase the risk of conflict and contradiction by creating or exacerbating the problem of application of multiple laws to transnational contractual networks.

The goal of countering the external risks that transnational contractual networks create requires private international law, at the very least, not to hinder third parties who suffer harm as a result of the activities of a network from pursuing effective proceedings against both the network member to which they were directly exposed and the network members who participated in the generation and realisation of risk. Private international law rules in the UK fail in this respect. The interaction between the recent changes introduced in the system of 
legal fees by the Legal Aid, Sentencing and Punishment of Offenders Act 2012 and the choice-of-law rules of Rome II means that claimants can only recover from defendants 'reasonable' costs (as opposed to 'necessary' costs) and that any success fee is now to be deducted from the damages awarded (as opposed being recoverable from defendants), the amount of which is arguably decreased because of the fact that the Rome II subjects this issue to the lex delicti and not the lex fori (as used to be the case under the English common law choice-of-law rules for torts). Coupled with the fact that claims that are based on a direct duty of care owed to a third party victim by a network member who was not directly exposed to third parties have very little chance of succeeding, the interaction between the rules on litigation funding and Rome II eliminates the incentives for lawyers to take on cases on a nowin no-fee basis.

There are several ways in which European private international law could be made more suitable for dealing with transnational contractual networks. The two Rome Regulations should give more weight to the organisational aspects of networks and the objective of unity of applicable law, for example by making the default choice-of-law rules, implied choice and the escape clauses more sensitive to the context of networks and by allowing the application of non-state rules of law. A factor to be taken into account when deciding on the application of overriding mandatory rules should be the potential undermining of the objectives of network regulation. Finally, third parties who suffer harm as a result of the activities of a network should have the possibility to pursue effective proceedings against all network members who participated in the generation and realisation of risk. This can only be achieved if adequate substantive law rules, either of national or transnational nature, and procedural law rules are in place alongside adequate private international law rules. 